tions which have been implicit in the modest stream of constructive criticism which has come, during this unhappy period, from the only consistent source of commentary on the condition of the British research enterprise - the House of Lords Select Committee on Science and Technology. From the outset, in a report published in 1981, the committee has been pleading for a mechanism by which science and technology, in their own right and not as ingredients of some department's larger programme, should have some kind of political representation in the machinery of government. Last year (see Nature 325, 95; 1987) the committee repeated its demand in an even more persuasive form: not merely should there be a minister (other than the Prime Minister, who has a science degree) but also an advisory council including independent members that would have a say in the direction of events. The members of the committee, and the House of Lords in general, will have a chance further to pursue this cause in the debate arranged for Thursday of this week. They should push hard, but prudently (which is their habit).

Much of what has damaged British science in the past fifteen years or so has been done in the name of good sense. In the old days, two decades ago, there were no difficulties in the allocation of resources (for technical people knew what the needs were), but even the governments of those halycon days (and their successors) would have benefitted from a means of knowing whether the funds spent so generously were also spent wisely and effectively. When it first became apparent (in the early 1970 s) that it would not be possible for budgets to keep on rising, but that they might even have to shrink, those concerned did not understand the system well enough to know what should be done. It seemed sensible when those research councils whose prime function is the support of basic science responded to the prospect of stagnation by creating common facilities in principle accessible to all academic scientists; these same institutions, fifteen years later, are a large part of the reason why the support of creative people has become inflexible. Similarly, with the recent need, in Britain's serious economic condition, to cut back on public spending, it made sense for research to be put on the auction block. Ironically, the government's proper wish that, in the interests of good management, government departments should be responsible for their own spending meant that decisions about what to cut were left to people even less able to understand the difficulties. The way that the Ministry of Agriculture, Fisheries and Food has, during this period, played ducks and drakes with the research council responsible for agriculture is nothing but a scandal.

The lessons to be learned from this unhappy period are that politicians and civil servants have jointly ruined a previously splendid enterprise for the lack of a framework of policy within which to carry out their well-intentioned but often mistaken decisions. So much can be told from the way that government departments have recurrently been swept by fashions - such as the fad for information technology and 'relevance' - and have sought to attain worthy objectives by methods fated to be ineffectual, attempting to skew the pattern of research while neglecting the need for mechanisms to ensure that useful outcomes can be successfully applied. At the same time, important ingredients of the equation "research success = prosperity" have been left untouched - British military research remains too far apart from the rest of the British enterprise. During this whole period, these errors of commission and omission would have been less easily foisted on the system if there had been a formal (if small) part of the machinery of government with the authority to question political decisions touching science and its application. For the advice to be that of an independent council would have the further benefit of helping to bring important issues out into the open and of providing a measure of continuity conspicuous by its absence in the management of British research. The House of Lords report had much else to say last year, but this is the nub of its demand. Can the government say no yet again?

\section{Shades of green and blue}

The hostile reception to UK government plans to promote other uses of farmland is undeserved.

WrTH one wave of a $£ 25$ million wand, Britain's Minister of Agriculture, Mr Michael Jopling last week tried to turn beef into buildings and butter into beech woods. So began what is sure to become a growing campaign on the ground in Britain, as opposed to in the corridors of Brussels, to shrink the food mountains of Europe. An edifice to the sluggishness of Euopean politics, these mountains have continued to grow at the expense of the taxpayers who heavily subsidize farmers to produce more food than Europe can consume. Since there cannot be a British taxpayer who whole-heartedly approves of this, unless he is also a farmer, Mr Jopling (who happens to be a farmer) must have hoped for a generally favourable response to his plans to entice farmers, by means of money, to find alternative uses for some of their less-good land. Why, instead, was his wand-waving greeted with the kind of reception that is usually reserved for the wicked fairy in the Christmas pantomime?

One justifiable reason would have been that the alternatives were too limited. But they are not. Of the $£ 25$ million, $£ 10$ million is to be offered to persuade farmers to turn grassland into woodland, $£ 7$ million to pay them not to harm so-called Environmentally Sensitive Areas, and smaller sums to encourage forestry as well as farmhouse industries such as cheese-making and providing clotted cream teas for tourists. Moreover, except for the very best of land, the constraints on converting it to nonagricultural use are to be relaxed - that is, if the local planning authorities see fit to allow a mediocre field to be turned into a golf course or a cluster of 'exclusive georgian-style residence', they need no longer take into account the loss of potential beef, butter or milk.

Farmers, however, can small a rat a mile off. While having no objection to the prospect of selling at great profit a field or two to a property developer, they know that in general the changes are a harbinger of much worse to come from a government set on reducing public expenditure in general and farming subsidies in particular. Nor were those whose prime concern is for the environment to be found rooting for the minister. This being an election year, Mr Jopling had clearly hoped to gain 'green votes' by some of his measures. For example, by doubling the budget available for paying farmers to stick to traditional methods in Environmentally Sensitive Areas, it will be possible to ensure the protection of some more areas from the waiting list. And one cry of all environmentalists has been at least partly heeded by the promise that a certain proportion, perhaps 20 per cent, of any woodland planted under the proposed scheme of additional subsidy will have to consist of broad-leaved trees. Where $\mathrm{Mr}$ Jopling lost the 'green vote' - and is in danger also of losing the 'blue vote' of traditional Conservative voters from commuter belts - is in relaxing the restrictions on non-agricultural use of farmland, particularly with the ensuing prospect of urban sprawl.

It is possible to feel some sympathy for Mr Jopling. After being careful to feed the barracudas before dipping his toe in the water, he still found them hungry enough to attack. He and his counterpart in the Department of the Environment are now going to have to consider how best to proceed. The Environment Secretary would be wise to say more on how planning authorities are to interpret the relaxation of the agricultural factor in considering applications for redevelopment of farming land. After all, he is the final court of appeal for developers denied permission. But that apart, the best course of action of the government is to stand firm and carefully monitor the results. For this is only the start of a programme that will, by some accounts, convert 30 per cent of English farmland to other uses by the end of this century. Viewed in that light, Mr Jopling's pilot experiment is likely to do more good than harm. 